\title{
A comparison of field and laboratory tests of caisson foundations in sand and clay
}

\author{
R. B. KELLY*, G. T. HOULSBY ${ }^{\dagger}$ and B. W. BYRNE ${ }^{\dagger}$
}

\begin{abstract}
Laboratory tests applying vertical and moment loads to suction caissons founded in sand and clay have been conducted to simulate an equivalent series of field tests. The caissons used in the laboratory were $0.15 \mathrm{~m}, 0.2 \mathrm{~m}$ and $0.3 \mathrm{~m}$ in diameter, whereas those for the field tests were $1.5 \mathrm{~m}$ and $3.0 \mathrm{~m}$ in diameter. The loads applied to the caissons in the laboratory tests were scaled from those in the field tests, and the models were loaded in a near-identical manner to the field trials. The test results are presented in non-dimensional form for comparison. The non-dimensional laboratory data from moment loading tests were similar to the field data in most cases. However, the non-dimensional data from vertically loaded caisson tests in the laboratory and in the field show more significant differences, and possible reasons for these are discussed.
\end{abstract}

KEYWORDS: clay; field tests; foundations; model tests; sand
Des essais en laboratoire appliquant des charges de moment et verticales aux caissons à succion trouvés dans le sable et l'argile ont été réalisés pour simuler une série équivalente d'essais in situ. Les dimensions des caissons utilisés en laboratoire étaient de $0,15 \mathrm{~m}, 0,2 \mathrm{~m}$ et $0,3 \mathrm{~m}$ de diamètre, et de $1,5 \mathrm{~m}$ et $3,0 \mathrm{~m}$ de diamètre pour les essais in situ. Les charges appliquées aux caissons dans les tests de laboratoires ont été mises à l'échelle de celle observées pour les essais in situ, et les modèles ont été chargés selon une manière presque identique à celle des essais in situ. Les résultats des essais sont présentés sous une forme sans dimensions, pour comparaison. Dans la plupart des cas, les données sans dimensions du laboratoire obtenues pour les tests de charge de moment sont similaires à celles obtenues in situ. Cependant, les données sans dimensions des tests de caissons chargés verticalement en laboratoire et in situ montrent une différence plus significative. Les raisons possibles de cette différence sont également discutées.

\section{INTRODUCTION}

Suction caissons have been used to provide innovative solutions to deep-water foundation and anchoring problems during the last 15 to 20 years. For some of these projects, programmes of model testing designed to simulate prototype caisson behaviour have been conducted. Laboratory studies of small-scale model caissons at $1 g$ include Larsen (1989), Steensen-Bach (1992) and El-Gharbawy \& Olson (1998), whereas centrifuge studies were carried out by Watson et al. (2000), Bang et al. (2001), House \& Randolph (2001) and Clukey et al. (2003). Published data from field trials using larger-scale caissons are less common, but include Hogervorst (1980), Tjelta (1986), Dyvik et al. (1993) and Cho et al. (2003). In most of these studies, the data are used to calibrate theoretical models, which are then used to predict prototype behaviour. No attempt has been made to compare directly the load-displacement response of caissons at different scales. Such comparisons are, however, vital if model testing is to be used to predict field behaviour.

Recently, a wide-ranging programme of $1 g$ laboratory tests and larger-scale field trials investigating suction caissons as foundations for offshore wind turbines has been conducted at Oxford University and reported by Byrne (2000), Byrne et al. (2002, 2003), Kelly et al. (2003, 2004) and Houlsby et al. $(2005,2006)$. Suction caissons for offshore wind turbines will initially be founded in relatively shallow water. Compared with applications in the oil and gas industry they will have lower vertical loads, but proportionately higher moment and horizontal loads. As foundations for offshore wind

Manuscript received 7 February 2005; revised manuscript accepted 12 September 2006.

Discussion on this paper closes on 1 May 2007, for further details see p. ii.

* Coffey Geotechnics Pty Ltd, Australia, formerly Department of Engineering Science, University of Oxford, UK.

${ }^{\dagger}$ Department of Engineering Science, University of Oxford, UK. turbines, caissons may be arranged to form a tetrapod or a monopod structure. Caissons in the tetrapod arrangement resist the overturning moment through opposing vertical reactions, whereas a mono-caisson resists the applied moment directly. As in previous studies, the laboratory tests were designed to calibrate a theoretical model of caisson behaviour, and data from field tests were used to validate the model. However, unlike previous studies, a series of laboratory tests have been performed to shadow the field trials in order to directly investigate effects of scale. Vertical load tests in sand have been conducted using caissons with diameters of $0.15 \mathrm{~m}$ and $0.2 \mathrm{~m}$ in the laboratory to compare with a $1.5 \mathrm{~m}$ diameter caisson in the field. Moment load tests in sand were conducted using $0.2 \mathrm{~m}$ and $0.3 \mathrm{~m}$ diameter caissons in the laboratory and $3.0 \mathrm{~m}$ in the field. Moment tests in clay used $0.2 \mathrm{~m}$ diameter caissons in the laboratory and $3.0 \mathrm{~m}$ in the field. Cyclic loading tests involving purely vertical loading were not carried out as part of the field trials in clay. Dimensionless equations are described below to compare the laboratory and the field test data.

\section{DIMENSIONLESS EQUATIONS FOR COMPARISON OF LABORATORY AND FIELD TESTS}

Laboratory and field tests are compared on the basis that, in dimensionless terms, the stiffness and the strength should be similar in equivalent tests. Consider first the strength, which is assumed to be governed by a simple bearing capacity approach. In this case, a simple dimensional analysis suggests that, in clay, vertical and horizontal loads will scale by $s_{\mathrm{u}} R^{2}$ and moments by $s_{\mathrm{u}} R^{3}$, where $R$ is the caisson radius and $s_{\mathrm{u}}$ is a representative undrained strength.

For consideration of strength in drained sand, loads scale by $\gamma^{\prime} R^{3}$ and moments by $\gamma^{\prime} R^{4}$, where $\gamma^{\prime}$ is the unit weight. This form of scaling applies when the densities in laboratory and field are such that the bearing capacity factors are similar for the two cases. This will require the laboratory 
tests to be at a lower relative density than the field tests, to account for the reduction of friction angle with stress level. The tests reported here do not precisely satisfy this condition. However, the applied vertical loads were only a small fraction of the compressive bearing capacity, and, in this case, the issue of density appears to be less important, as evidenced by the successful use of the scaling approach described below. Other possible effects such as ageing and cementation in the field deposit of sand were minimised by using a freshly prepared bed of sand at the site (discussed in detail by Houlsby et al., 2006).

The consideration of stiffness is a little more complex. The elastic stiffness matrix for a caisson subjected to vertical, moment and horizontal loads, $V, M$, and $H$ loading, may be written as

$$
\left[\begin{array}{c}
V \\
M / 2 R \\
H
\end{array}\right]=2 R G\left[\begin{array}{ccc}
k_{1} & 0 & 0 \\
0 & k_{3} & k_{4} \\
0 & k_{4} & k_{2}
\end{array}\right]\left[\begin{array}{c}
w \\
2 R \theta \\
u
\end{array}\right]
$$

where $G$ is the shear modulus of the soil, $w, 2 R \theta$ and $u$ are vertical, rotational and horizontal displacements, and $k_{i}$ are dimensionless elastic constants

Consider the moment-rotation relationship which can be obtained from equation (1) as

$$
\frac{M}{\theta}=\frac{(2 R)^{3} G\left(k_{2} k_{3}-k_{4}^{2}\right)}{k_{2}-k_{4}(2 R H / M)}
$$

The shear modulus in sand is known to be related to the mean confining stress. One of the principal objections to modelling structures at small scale in the laboratory, at $1 g$, is that the stresses are much smaller than in the field. We therefore attempt to account for the stress level by expressing the shear modulus as

$$
\frac{G}{p_{\mathrm{a}}}=A\left(\frac{\sigma_{\mathrm{v}}^{\prime}}{p_{\mathrm{a}}}\right)^{n}
$$

where $p_{\mathrm{a}}$ is atmospheric pressure (used as a reference pressure), $\sigma_{\mathrm{v}}^{\prime}$ is a representative effective vertical stress, $A$ is a dimensionless constant and $n$ is the pressure exponent. Wroth et al. (1979) and Coop \& Jovicic (1999) have reported that the value of $n$ is not unique, but depends on the strain level. Wroth et al. (1979) suggest that $n$ ranges from 0.435 at very small strain to 0.765 at large strain. For Ham River silica sand, Coop \& Jovicic (1999) suggest that $n=0.59$ for very small strains. Wroth \& Houlsby (1985) suggest that a value of 0.5 would capture most of the important feature of the increase in stiffness with pressurethat is, that the stiffness increases approximately with the square root of stress level-and this value is used here to compare the laboratory and field data.

Both stress magnitude and strain amplitude will vary around the caisson and, to use equation (3), some representative stress is required to make an estimate of the shear modulus. An appropriate choice is to use the vertical stress at some depth $a R$ below the caisson, which may be estimated (neglecting load spreading effects) as

$$
\sigma_{\mathrm{v}}^{\prime}=\frac{V}{\pi R^{2}}+\gamma^{\prime}(h+a R)
$$

where $V$ is the applied vertical load, $h$ is the length of the caisson skirt and $a$ is a dimensionless constant.

Substituting equation (4) into equation (3) gives

$$
G=A p_{\mathrm{a}}^{(1-n)}\left(2 R \gamma^{\prime}\right)^{n}\left[\frac{4}{\pi} \frac{V}{\gamma^{\prime}(2 R)^{3}}+\frac{h}{2 R}+\frac{a}{2}\right]
$$

which in turn may be substituted into equation (2) to give

$$
\begin{aligned}
\frac{M}{\gamma^{\prime}(2 R)^{4}}= & \theta\left(\frac{p_{\mathrm{a}}}{2 R \gamma^{\prime}}\right)^{(1-n)} \\
& {\left[\frac{A\left(k_{2} k_{3}-k_{4}^{2}\right)}{k_{2}-k_{4}(2 R H / M)}\right]\left(\frac{4}{\pi} \frac{V}{\gamma^{\prime}(2 R)^{3}}+\frac{h}{2 R}+\frac{a}{2}\right)^{n} }
\end{aligned}
$$

If tests at different scales are conducted keeping $M / 2 R H$, $V / \gamma^{\prime}(2 R)^{3}$ and $h / 2 R$ constant, and taking $n$ to be $0 \cdot 5$, then the moments and rotations in these tests will be related by

$$
\frac{M}{\gamma^{\prime}(2 R)^{4}}=\theta\left(\frac{p_{\mathrm{a}}}{2 R \gamma^{\prime}}\right)^{0.5} f_{1}\left(\frac{M}{2 R H}, \frac{V}{\gamma^{\prime}(2 R)^{3}}, \frac{h}{2 R}\right)
$$

where $f_{1}$ is a dimensionless function. This suggests that satisfactory comparison of both stiffness and strength for moment tests in sand can be achieved by plotting $M / \gamma^{\prime}(2 R)^{4}$ against $\theta\left(p_{\mathrm{a}} / 2 R \gamma^{\prime}\right)^{0.5}$.

A similar process can be conducted for cyclic vertical loading in sand, giving

$$
\frac{V}{\gamma^{\prime}(2 R)^{3}}=\frac{w}{2 R}\left(\frac{p_{\mathrm{a}}}{2 R \gamma^{\prime}}\right)^{0.5} f_{2}\left(\frac{V_{\mathrm{m}}}{\gamma^{\prime}(2 R)^{3}}, \frac{h}{2 R}\right)
$$

where $V_{\mathrm{m}}$ has been introduced as a mean vertical load during the test, which may be used to estimate an appropriate shear modulus. Equation (8) suggests that vertical loading data can be compared by plotting $V / \gamma^{\prime}(2 R)^{3}$ against $(w / 2 R)\left(p_{\mathrm{a}} /\right.$ $\left.2 R \gamma^{\prime}\right)^{0.5}$ for tests at similar values of $V_{\mathrm{m}} / \gamma^{\prime}(2 R)^{3}$ and $h / 2 R$.

A similar analysis can be applied to moment-rotation loading in clay, except that the shear modulus is taken to be proportional to the undrained shear strength of the clay, assuming the overconsolidation ratios for the clays are similar in the laboratory and in the field (e.g. Wroth \& Houlsby, 1985). The result is

$$
\frac{M}{s_{\mathrm{u}}(2 R)^{3}}=\theta f_{3}\left(\frac{M}{2 R H}, \frac{V}{s_{\mathrm{u}}(2 R)^{2}}, \frac{h}{2 R}, \text { OCR }\right)
$$

which suggests that $M / s_{\mathrm{u}}(2 R)^{3}$ may be plotted directly against $\theta$ for tests with similar values of the arguments of function $f_{3}$.

Finally, for the case of vertical loading in clay (which we record here for completeness, although no such comparisons are made later in the paper), the results could be expressed as

$$
\frac{V}{s_{\mathrm{u}}(2 R)^{2}}=\frac{w}{2 R} f_{4}\left(\frac{V_{\mathrm{m}}}{s_{\mathrm{u}}(2 R)^{2}}, \frac{h}{2 R}, \mathrm{OCR}\right)
$$

which suggests that $V / s_{\mathrm{u}}(2 R)^{2}$ be plotted against $w / 2 R$ for tests with similar values of the arguments of function $f_{4}$.

The dimensionless mean vertical loads applied to the caissons must be similar for the above procedures to be used to compare the test data, so that these mean loads are similar fractions of the bearing capacity of the foundation. Butterfield \& Gottardi (1994), and others, have shown that the rotational and translational capacity of a shallow footing depends on the applied mean vertical load as a proportion of the ultimate vertical capacity. This is the reason for requiring similarity of $V_{\mathrm{m}} / \gamma^{\prime}(2 R)^{3}$ or of $V_{\mathrm{m}} / s_{\mathrm{u}}(2 R)^{2}$ as well as of density or OCR in equation (8) or equation (10).

\section{FIELD TRIALS}

The field trials of suction caissons in sand and clay were conducted from December 2003 to March 2004 in Scotland. 
The clay site was at Bothkennar, near Stirling, and a full description of the field tests there is given by Houlsby et al. (2005). Bothkennar was the EPSRC geotechnical test site, and Nash et al. (1992) have comprehensively described the properties of the high-plasticity silty clay at that site. A test pit was dug, $20 \mathrm{~m}$ long by $10 \mathrm{~m}$ wide by $1.75 \mathrm{~m}$ deep. The base of the pit lay just beneath a shelly layer described by Nash et al. (1992). The undrained shear strength of the silty clay at this level, as inferred from Nash et al. (1992), was $11.4 \mathrm{kPa}$, increasing linearly by $1.96 \mathrm{kPa} / \mathrm{m}$. The pit was flooded with water to a depth of $200 \mathrm{~mm}$. A $3 \mathrm{~m}$ diameter caisson having a skirt $1.5 \mathrm{~m}$ long and a wall thickness of $8 \mathrm{~mm}$ was installed at two locations within the pit using suction. A $1 \mathrm{~m}^{3}$ concrete block was placed on the lid of the caisson to provide a constant vertical load in addition to the self-weight of the caisson. Cyclic horizontal loads were applied $4.23 \mathrm{~m}$ above the lid of the caisson using a hydraulic jack mounted between a separate reaction frame and a double A-frame structure fixed to the caisson. Fig. 1 shows a photo of the test site with the loading rig in place and the $3 \mathrm{~m}$ caisson ready to be installed. The loads applied to the caisson were measured by shear pin load cells attached to the hydraulic jack. Displacements were measured using draw-wire sensors attached to a reference frame installed around the caisson. Cyclic horizontal loads, with the load amplitude increasing by $5 \mathrm{kN}$ per cycle, were applied to the caisson at its first location. Similar tests were conducted at the second location, but a packet of 10 cycles with horizontal load amplitude of $\pm 20 \mathrm{kN}$ was included within the test programme.

The sand site was at Luce Bay, near Stranraer, and a full description of the field tests there is given by Houlsby et al. (2006). A purpose-built sand embankment was constructed from spoil material within a working sand and gravel quarry at Luce Bay. The spoil material consisted of $85 \%$ fine to medium-grained silica sand, $15 \%$ fine to coarse-grained gravel with the occasional cobble and peat inclusion. The embankment was constructed in a worked-out area of the quarry during the summer of 2003, when the water table was low. The embankment was constructed in layers $250 \mathrm{~mm}$ thick, which were compacted using the tracks of the construction machinery. The embankment was about $40 \mathrm{~m}$ long by $10 \mathrm{~m}$ wide and $3.5 \mathrm{~m}$ deep. Cone penetrometer tests and maximum and minimum density tests were performed by Fugro Ltd to determine the properties of the sand (Robinson et al., 2004; Whittle, 2004). The maximum and minimum dry unit weights of the sand were $17 \cdot 8 \mathrm{kN} / \mathrm{m}^{3}$ and $13.7 \mathrm{kN} / \mathrm{m}^{3}$ respectively. The relative density of the com-

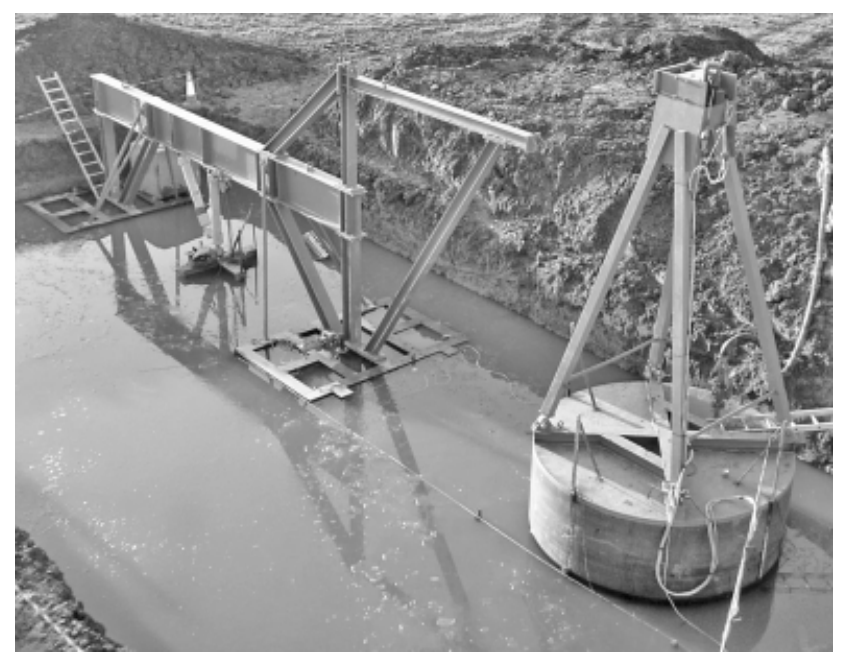

Fig. 1. Field testing at Bothkennar, showing the $3 \cdot 0 \mathrm{~m}$ caisson in place for installation pacted sand was inferred from the cone penetrometer data to be $80-85 \%$. The submerged unit weight at a relative density of $80 \%$ was determined to be $10 \cdot 3 \mathrm{kN} / \mathrm{m}^{3}$. The field tests were conducted in the winter, when the water table had risen above the top of the embankment.

Two caissons were tested at Luce Bay: a $1.5 \mathrm{~m}$ diameter caisson, which had a skirt length of $1 \mathrm{~m}$ and a thickness of $8 \mathrm{~mm}$, and the $3 \mathrm{~m}$ diameter caisson previously used at Bothkennar. Both caissons were installed using suction. The $1.5 \mathrm{~m}$ caisson was loaded using a hydraulic jack attached to the caisson and a reaction frame. Packets of 10 cycles with amplitudes increasing by $\pm 10 \mathrm{kN}$ per packet up to $\pm 100 \mathrm{kN}$ were applied to the caisson about a mean load of $60 \mathrm{kN}$. The loads were again measured using the clevis pin load cells, and the displacements by draw-wire sensors fixed to an independent reference frame. The $3.0 \mathrm{~m}$ diameter caisson was again installed at two locations. In the first test it was loaded in a similar manner to the test at Bothkennar. Packets of 10 cycles were applied in the second test at horizontal load amplitudes of $\pm 10 \mathrm{kN}, \pm 20 \mathrm{kN}, \pm 40 \mathrm{kN}$ and $\pm 60 \mathrm{kN}$.

\section{LABORATORY TESTS}

The laboratory tests were conducted using test beds constructed from Redhill 110 sand and Speswhite kaolin clay. Redhill 110 is a poorly graded fine-grained silica sand. It has maximum and minimum dry unit weights of $16.8 \mathrm{kN} / \mathrm{m}^{3}$ and $12.8 \mathrm{kN} / \mathrm{m}^{3}$ respectively. Saturated test beds $350 \mathrm{~mm}$ deep were constructed in a container $1.1 \mathrm{~m}$ in diameter. The samples were densified using vibration.

The kaolin was consolidated from slurry in two $450 \mathrm{~mm}$ diameter containers to create $430 \mathrm{~mm}$ high test beds. It was consolidated in stages over a period of one month, and was subject to a maximum pressure of $200 \mathrm{kPa}$. The undrained shear strengths of the clay, inferred from shear vane tests, were $10.8 \mathrm{kPa}$ and $9.0 \mathrm{kPa}$ at the surface of the two containers, increasing to $12.4 \mathrm{kPa}$ at a depth of $100 \mathrm{~mm}$ in both containers.

Four caissons were used in the laboratory tests, two with an aspect ratio (length to diameter) of 0.66 , which were used to model the $1.5 \mathrm{~m}$ field caisson, and two with an aspect ratio of 0.5 to model the $3.0 \mathrm{~m}$ field caisson. The caisson geometry, test bed properties and mean vertical loads applied to the caissons are given in Tables $1-4$ for the vertical load tests in sand, moment load tests in sand and in clay. The mean vertical loads applied to the field caissons in Tables 1-4 include the self-weight of the caissons.

In the laboratory, the caissons were installed either by suction or by pushing in sand, and just by pushing in the clay. The loads were applied using a three-degree-of-freedom test rig designed by Martin (1994) and shown in Fig. 2. The rig can control vertical, horizontal and moment loads, or displacements, independently to follow a desired load path (Byrne, 2000). The loads were recorded using a Cambridgetype load cell (Bransby, 1973), and vertical, horizontal and rotational displacements were recorded using LVDTs.

In the laboratory tests, the cyclic vertical loads were loadcontrolled. In contrast, the tests applying overturning moments were controlled by applying fixed rotations scaled from the field trial values.

\section{COMPARISON OF LABORATORY AND FIELD TEST DATA IN SAND}

Vertical load tests

In the following it should be made clear that positive loads and positive displacements are taken as downwards. A tensile load on the caisson is therefore negative.

Data from laboratory tests on $0.15 \mathrm{~m}$ diameter caissons, 
Table 1. Caisson geometry and soil properties for vertical load tests in sand

\begin{tabular}{l|c|c|c|c|c|c}
\hline $\begin{array}{l}\text { Diameter: } \\
\mathrm{m}\end{array}$ & $\begin{array}{c}\text { Installation } \\
\text { method }\end{array}$ & $\begin{array}{c}\text { Unit weight: } \\
\mathrm{kN} / \mathrm{m}^{3}\end{array}$ & $\begin{array}{c}\text { Relative } \\
\text { density }\end{array}$ & $\begin{array}{c}\text { Mean load: } \\
\mathrm{kN}\end{array}$ & $\begin{array}{c}\text { Aspect ratio, } \\
h / D\end{array}$ & $t / D$ \\
\hline $1 \cdot 5$ & Suction & $10 \cdot 3$ & $0 \cdot 80$ & 66 & 0.66 & $0 \cdot 0053$ \\
$0 \cdot 2$ & Pushing & $10 \cdot 0$ & $0 \cdot 84$ & $0 \cdot 152$ & 0.66 & $0 \cdot 0165$ \\
$0 \cdot 15$ & Suction & $9 \cdot 5$ & 0.69 & 0.065 & 0.66 & 0.0067 \\
$0 \cdot 15$ & Pushing & $9 \cdot 7$ & 0.77 & 0.062 & $0 \cdot 66$ & 0.0067 \\
\hline
\end{tabular}

Table 2. Caisson geometry and soil properties for moment load tests in sand with increasing cyclic amplitude

\begin{tabular}{l|c|c|c|c|c|c}
\hline $\begin{array}{l}\text { Diameter: } \\
\mathrm{m}\end{array}$ & $\begin{array}{c}\text { Installation } \\
\text { method }\end{array}$ & $\begin{array}{c}\text { Unit weight: } \\
\mathrm{kN} / \mathrm{m}^{3}\end{array}$ & $\begin{array}{c}\text { Relative } \\
\text { density }\end{array}$ & $\begin{array}{c}\text { Mean load: } \\
\mathrm{kN}\end{array}$ & $\begin{array}{c}\text { Aspect ratio, } \\
h / D\end{array}$ & $t / D$ \\
\hline $3 \cdot 0$ & Suction & $10 \cdot 3$ & $0 \cdot 80$ & $42 \cdot 4$ & $0 \cdot 5$ & $0 \cdot 0027$ \\
$0 \cdot 3$ & Pushing & $10 \cdot 0$ & $0 \cdot 84$ & $0 \cdot 041$ & $0 \cdot 5$ & $0 \cdot 0117$ \\
$0 \cdot 2$ & Suction & $9 \cdot 5$ & 0.69 & $0 \cdot 012$ & $0 \cdot 5$ & $0 \cdot 0050$ \\
$0 \cdot 2$ & Pushing & $9 \cdot 7$ & $0 \cdot 77$ & $0 \cdot 012$ & $0 \cdot 5$ & $0 \cdot 0050$ \\
\hline
\end{tabular}

Table 3. Caisson geometry and soil properties for moment load tests in sand with packets of cycles

\begin{tabular}{l|c|c|c|c|c|c}
\hline $\begin{array}{l}\text { Diameter: } \\
\mathrm{m}\end{array}$ & $\begin{array}{c}\text { Installation } \\
\text { method }\end{array}$ & $\begin{array}{c}\text { Unit weight: } \\
\mathrm{kN} / \mathrm{m}^{3}\end{array}$ & $\begin{array}{c}\text { Relative } \\
\text { density }\end{array}$ & $\begin{array}{c}\text { Mean load: } \\
\mathrm{kN}\end{array}$ & $\begin{array}{c}\text { Aspect ratio, } \\
h / D\end{array}$ & $t / D$ \\
\hline $3 \cdot 0$ & Suction & $10 \cdot 3$ & $0 \cdot 80$ & $42 \cdot 4$ & $0 \cdot 5$ & $0 \cdot 0027$ \\
$0 \cdot 3$ & Pushing & $10 \cdot 0$ & $0 \cdot 84$ & $0 \cdot 041$ & $0 \cdot 5$ & $0 \cdot 0117$ \\
$0 \cdot 2$ & Pushing & $10 \cdot 0$ & $0 \cdot 84$ & $0 \cdot 012$ & $0 \cdot 5$ & $0 \cdot 0050$ \\
\hline
\end{tabular}

Table 4. Caisson geometry and soil properties for all moment load tests in clay

\begin{tabular}{l|c|c|c|c|c}
\hline $\begin{array}{l}\text { Diameter: } \\
\mathrm{m}\end{array}$ & $\begin{array}{c}\text { Installation } \\
\text { method }\end{array}$ & $s_{\mathrm{u}}: \mathrm{kN} / \mathrm{m}^{2}$ & $\begin{array}{c}\text { Mean load: } \\
\mathrm{kN}\end{array}$ & $\begin{array}{c}\text { Aspect ratio, } \\
h / D\end{array}$ & $t / D$ \\
\hline $3 \cdot 0$ & Suction & $14 \cdot 4$ & $42 \cdot 4$ & 0.5 & $0 \cdot 0027$ \\
$0 \cdot 2$ & Pushing & $12 \cdot 4$ & $0 \cdot 162$ & 0.5 & $0 \cdot 0050$ \\
\hline
\end{tabular}

where one caisson was installed by pushing and one by suction, are compared with data from the vertical field test in Figs 3(a) and 3(b). In each test, packets of cycles of increasing amplitude were applied. There are two key features of the behaviour during the cycling: (a) the stiffness in a given cycle; and (b) the accumulation of deformation over several cycles. It is immediately apparent from Fig. 3(a) that larger accumulated deformation occurred in the laboratory test in which suction was used for installation than in the test with pushed installation. This is attributed to the probable loosening of the sand adjacent to the caisson during the suction installation. By comparison the accumulated deformations in the field test (also suction installed, but a caisson 10 times larger), Fig. 3(b), fall between the two laboratory tests in terms of the dimensionless plot. The implication is that disturbance due to suction installation is relatively less important for the larger caisson, which seems entirely plausible. Suction installation may create a localised zone of disturbance adjacent to a caisson, which does not increase in proportion to caisson diameter.

Figures 4(a) and 4(b) show two laboratory tests of slightly different sizes, both with pushed installation. The larger test shows less accumulated deformation, supporting the hypothesis that accumulated deformation reduces with scale. Significantly more accumulated deformation occurs in suctioninstalled tests than with pushed installation. These trends are shown in Fig. 5, in which the accumulated deformations are plotted against cycle number. (Note that the cyclic load amplitude increases every 10 cycles.) In most cases the accumulated deformations were downwards, except for the smaller caisson installed by pushing, which initially moved slightly upwards as the cyclic loads were applied, and moved downwards only when the minimum vertical loads became tensile. Although it is slightly counter-intuitive that tensile loads should cause net downward movement, it should be recalled that, even in cycles in which the minimum load was tensile, the average load for the cycle was compressive. Although clear qualitative trends can be discerned from the data, it is difficult without more test data to quantify the accumulated deformations as a function of size, loading amplitude and installation method. Differences between the tests may also be attributable to minor variations in relative density.

Turning now to stiffness, Fig. 6 shows the dimensionless stiffness plotted as a function of dimensionless cyclic rotation amplitude (on a logarithmic scale). The stiffness is in each case defined as the secant stiffness over the unloading branch of a cycle (which differs slightly from the secant stiffness on loading because of the influence of the accumulated deformation). This plot may be compared with the shape of a typical plot of shear modulus against shear strain amplitude. It is clear that the stiffness drops rapidly with 


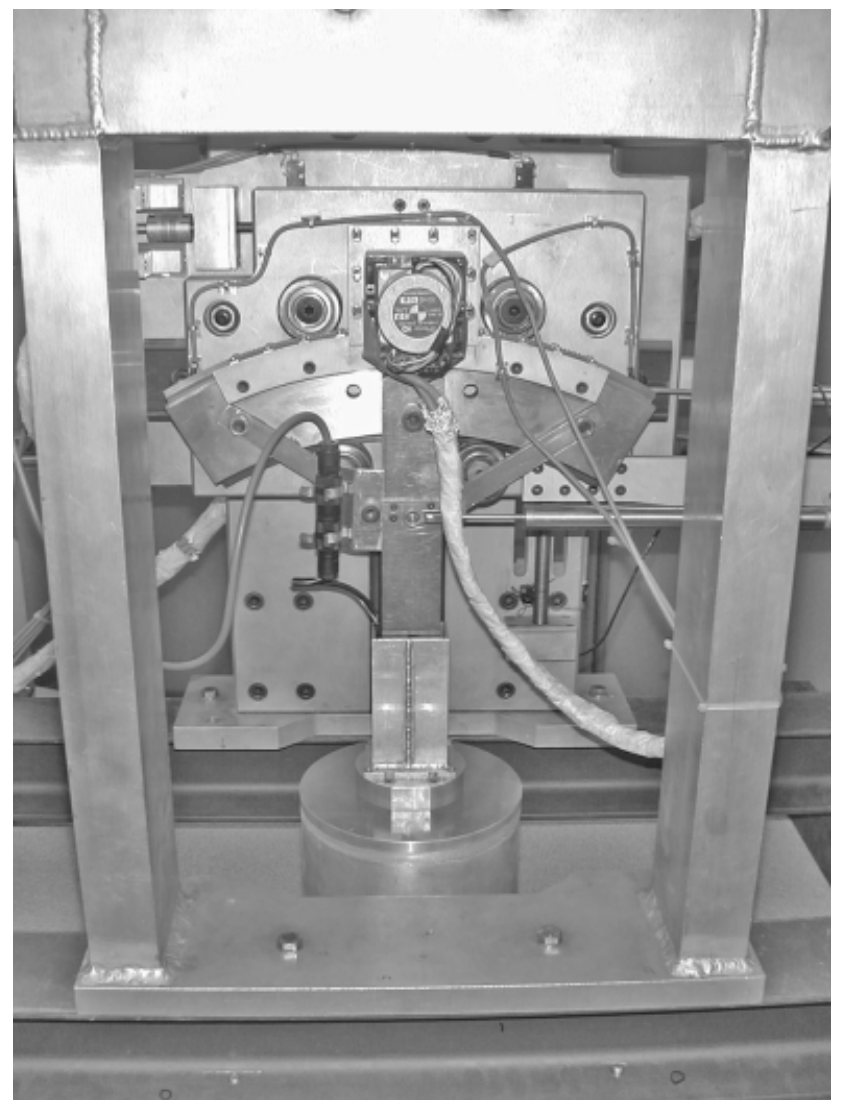

Fig. 2. Three-degree-of-freedom loading rig at Oxford University

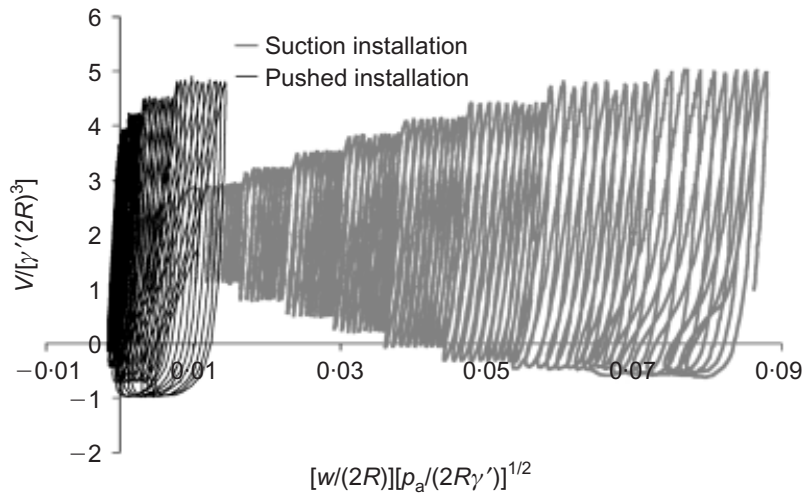

(a)

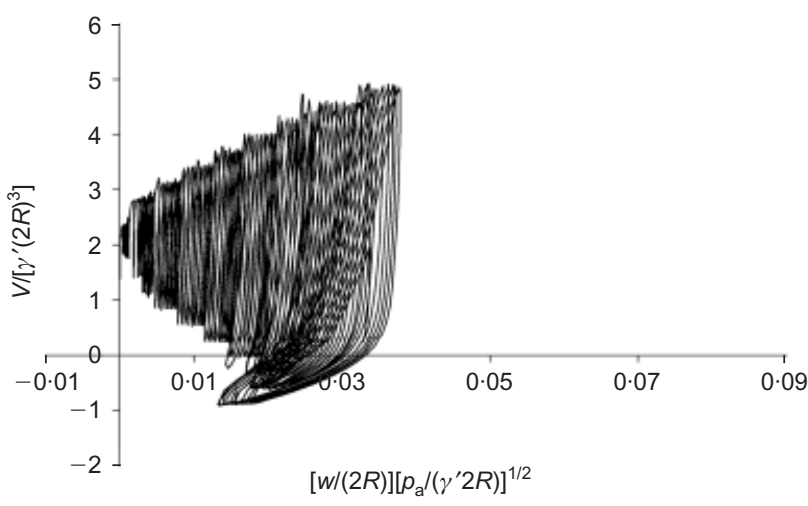

(b)

Fig. 3. Vertical load: (a) laboratory test data, $0 \cdot 15 \mathrm{~m}$ diameter caissons; (b) field test data, $1.5 \mathrm{~m}$ diameter caisson

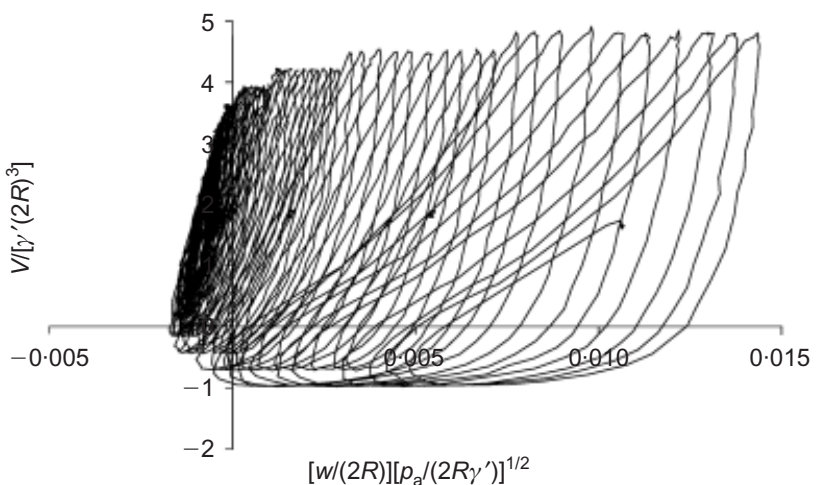

(a)

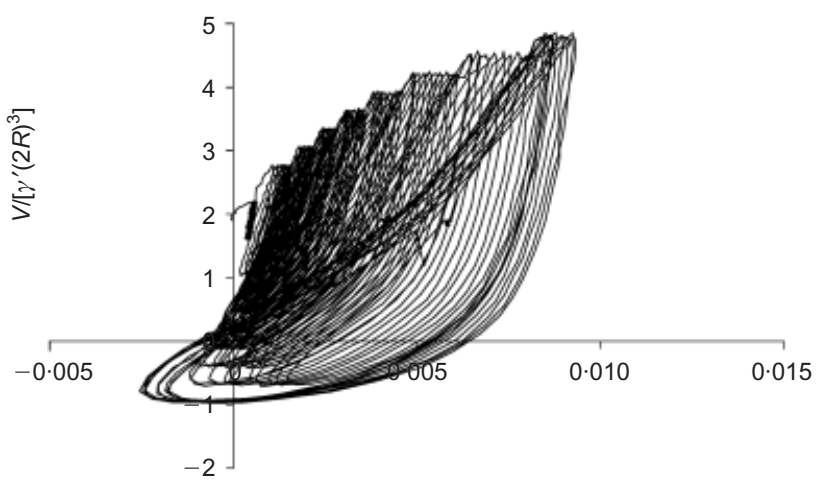

$[W /(2 R)]\left[p_{a} /\left(2 R \gamma^{\prime}\right)\right]^{1 / 2}$

(b)

Fig. 4. Laboratory test, pushed installation: (a) $0 \cdot 15 \mathrm{~m}$ diameter caisson; (b) $0.2 \mathrm{~m}$ diameter caisson

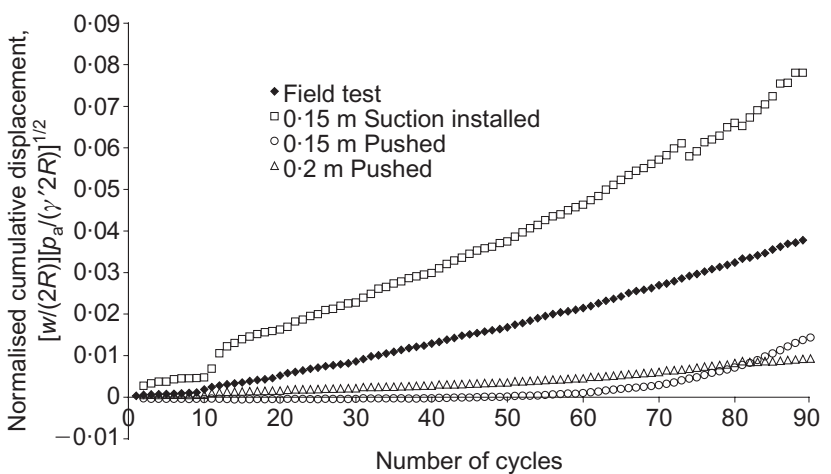

Fig. 5. Cumulative displacements during vertical loading as a function of cycle number

cyclic amplitude, but laboratory and field tests show remarkably similar trends, indicating that the method for normalising the data is highly successful in achieving comparability of stiffness in any one cycle. Such comparability is, in fact, apparent from the shapes of the larger cycles that can be seen in Figs 3 and 4: in each case the shape and size of each individual cycle is closely comparable, with the differences between tests being attributable mainly to the accumulated deformations. This point is emphasised in Fig. 7, in which individual cycles at small, medium and large amplitudes (left-hand, middle and right-hand groups of curves respectively) from the different tests have been superimposed at normalised scale. Within each group of curves are tests at different scales denoted by the captions in the figure legend.

Note that the data fall onto two well-defined curves in 


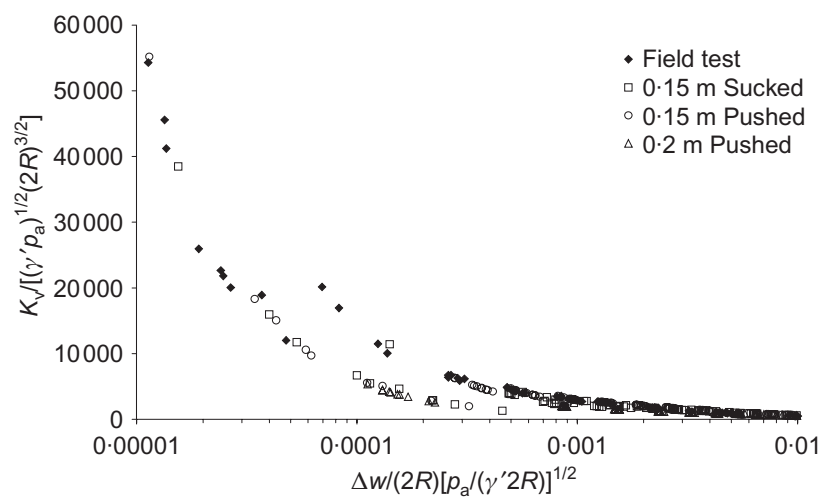

Fig. 6. Normalised vertical unloading stiffness plotted against normalised displacement

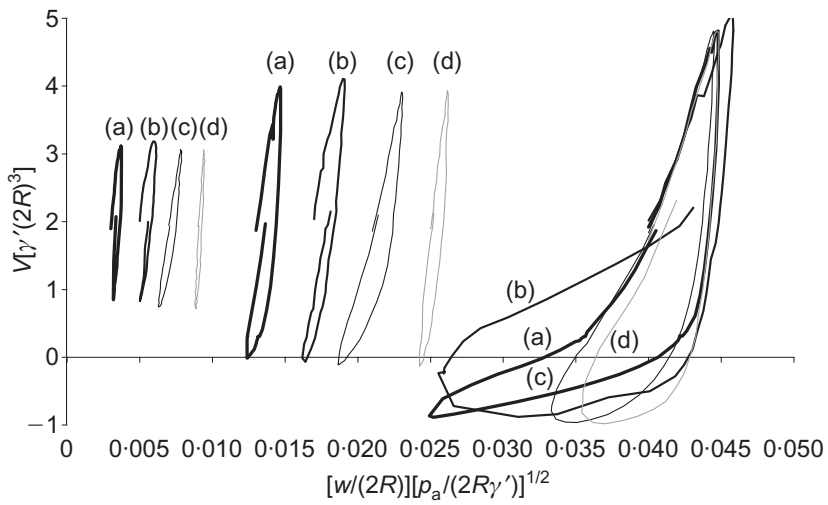

Fig. 7. Superimposed small, medium and large cycles of vertical displacement from different tests: (a) $1.5 \mathrm{~m}$ field; (b) $0.15 \mathrm{~m}$ suction installed; (c) $0.2 \mathrm{~m}$ pushed; (d) $0.15 \mathrm{~m}$ pushed

Fig. 6. The left-hand curve relates to the first set of cycles in each test, and the right-hand curve to the remaining cycles in each test. The apparent separation in the data is, to a certain extent, an artefact of the requirement that, for each load amplitude, the points should fall on a single curve.

The variation of stiffness during packets of cycles is explored in more detail in Fig. 8, which shows the unloading stiffness plotted against cycle number. Note that after each 10 cycles the load amplitude is increased, resulting in a lower stiffness. During each packet of cycling, however, there is no discernible trend of variation of stiffness. Fig. 8 also highlights differences of stiffness between the tests that are more apparent here than in Fig. 6. It should be emphasised, though, that the normalisation process involves a factor of about 33 between the stiffness in the largest and smallest tests: the remaining differences, which fall within a

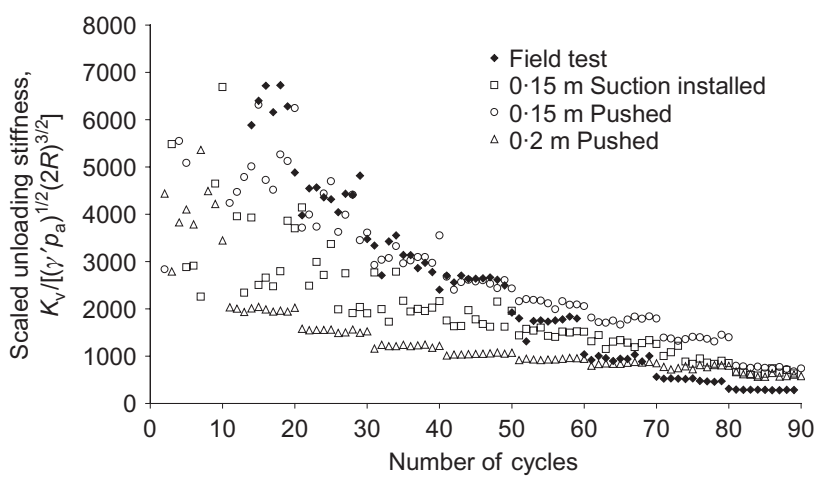

Fig. 8. Variation of normalised stiffness with cycle number factor of about two, should be viewed within this context. Note that on the normalised scale the field tests at small amplitude appear rather stiffer than the laboratory test, whereas at larger amplitude they are less stiff. This systematic variation may be attributable to the fact that different values of the exponent $n$ in equation (3) would be applicable at different amplitudes of rotation.

Note in Fig. 7 that, as cyclic amplitude increases, the hysteresis loops become more open (damping increases). Once cycles become sufficiently large that the minimum vertical load becomes tensile, a transition to a much more flexible response occurs and the hysteresis loops acquire a characteristic 'banana' shape (see Fig. 7), similar to that reported by Byrne \& Houlsby (2002). For practical foundation designs it seems prudent to avoid this more flexible behaviour, so that caisson foundations should be designed to avoid tensile loading. Note that, paradoxically, the rate of accumulated downward movement increases once tensile loading is reached. A possible explanation is that the substantial upward movement during a tensile loading cycle causes loosening of the sand, which (because the average load in the cycle is compressive) allows a net downward movement. Clearly this downward movement could not continue indefinitely, because the foundation would become stiffer as it penetrated the soil more deeply.

\section{Moment load tests}

Data from the moment loading laboratory and field tests, where the load amplitude increased with each cycle, are compared in Figs 9(a) and 9(b). The rotations in the laboratory tests were scaled directly from the field tests to allow the resulting moment loads to be compared.

The first few cycles during the laboratory test are shown in Fig. 10(a). The scatter in the data reflects noise affecting

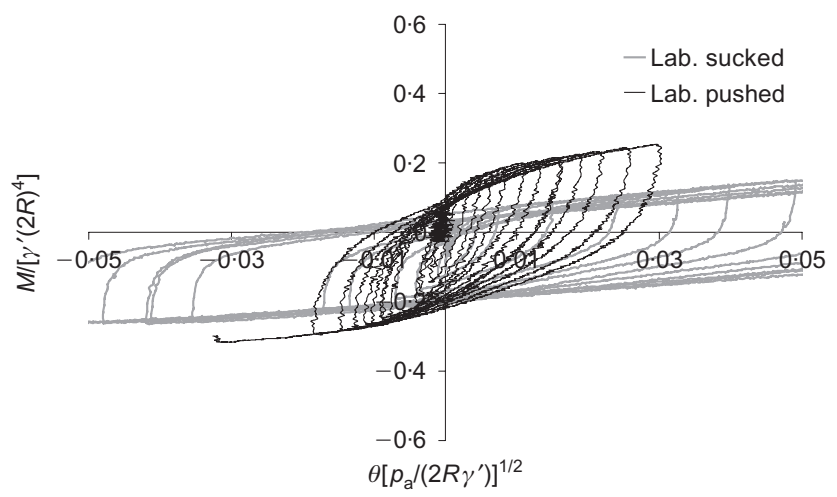

(a)

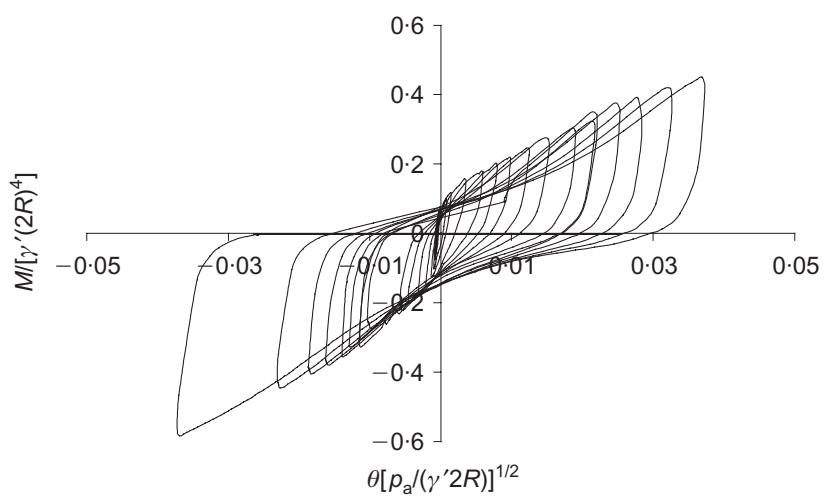

(b)

Fig. 9. Moment loading: (a) laboratory test data, $0 \cdot 2 \mathrm{~m}$ diameter caisson; (b) field test data, 3.0 m diameter caisson 


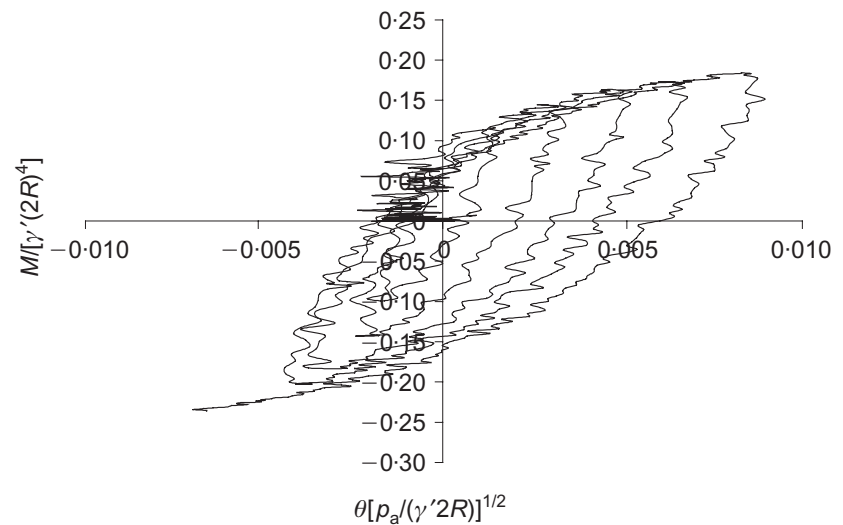

(a)

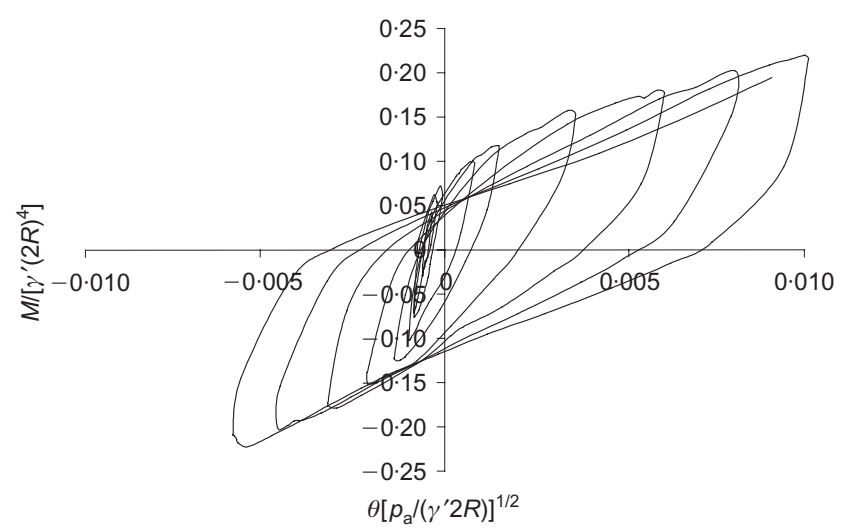

(b)

Fig. 10. Small deformation moment loading: (a) $0 \cdot 2 \mathrm{~m}$ diameter caisson; (b) 3.0 m diameter caisson

the transducer readings at the very small displacements applied to the caisson. The shape of the normalised moment-rotation curves in the laboratory test with pushed installation and in the field test were similar at small rotations (see Figs 10(a) and 10(b)), but diverged as the magnitude of the rotations increased (Fig. 9). The characteristic shape of the hysteresis loops at large rotations in the field trial was due to gapping between the caisson and the sand (which was observed visually). Gapping was not observed in the laboratory test. This may be because the absolute (as opposed to normalised) magnitude of the rotations in the laboratory tests was much smaller than that in the field test. The process of normalisation of loads and stiffness is therefore unable to account entirely for all phenomena observed, although it seems very satisfactory at small rotations. The fact that the magnitudes and shapes of the curves in Figs 10(a) and 10(b) are similar is a very significant result. Foundations for offshore wind turbines are likely to be designed to operate in the range of normalised rotations shown in Figs 10(a) and 10(b) rather than at larger deformations, as shown in Fig. 9, where the normalised responses of the field and laboratory caissons differ. The maximum normalised moment continued to increase with rotation amplitude in the field trial, whereas it seemed to approach a limit in the laboratory test. The normalised moment loads were significantly smaller in the laboratory test where the caisson was installed by suction, again indicating a detrimental effect of sand disturbance during installation at small scale.

The normalised moment-rotation responses in laboratory and field tests in sand, where packets of 10 cycles were applied to the caissons, are shown in Figs 11(a) and 11(b). The normalised behaviour of the caissons is again similar at

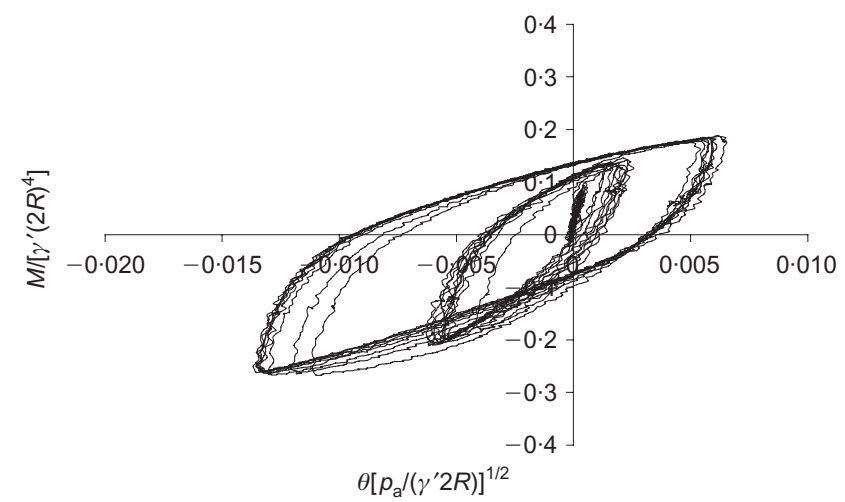

(a)

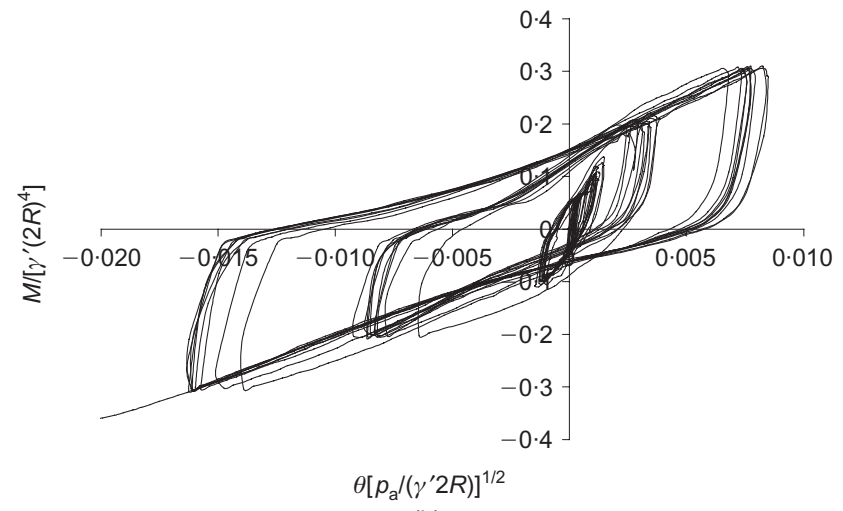

(b)

Fig. 11. Multiple cycle moment loading: (a) laboratory test data, $0.2 \mathrm{~m}$ diameter caisson; (b) field test data, 3.0 m diameter caisson

small rotations, and becomes increasingly different as the deformations increase. Although the shapes of the loops are dissimilar, in fact the loads achieved at comparable normalised rotations were very similar. Again the characteristic shape of the hysteresis loops in the field test is thought to be due to gapping at the side of the caisson.

Normalised unloading stiffness data for all of the moment loading tests are presented in Fig. 12. The unloading stiffness is again defined as the peak-to-peak normalised moment divided by the normalised rotation during the unloading half cycle. The normalised unloading stiffnesses are remarkably similar for all of the tests, taking into consideration that the scaling incorporates a factor in excess of 13600 , which results from incorporating a stress-depen-

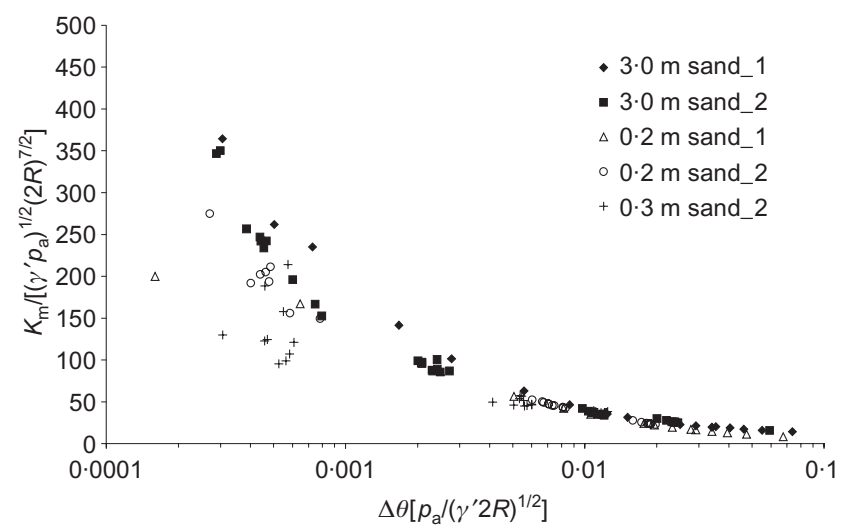

Fig. 12. Normalised unloading stiffness data for moment load tests in sand 
dent stiffness into the non-dimensional equations as well as from the direct scaling factor.

\section{COMPARISON OF LABORATORY AND FIELD DATA IN CLAY}

Data from the first field test at Bothkennar are compared with laboratory test data in Figs 13(a) and 13(b). The normalised strength and stiffness are (as for the sand) more similar at low rotations (Fig. 14) than at larger rotations (Fig. 13). Data from the initial few cycles in these tests in Figs 13(a) and 13(b) show a good correlation between the normalised behaviour to rotations up to about $0.0015 \mathrm{rad}$, although the caisson in the laboratory test showed a slightly stiffer response. The ultimate capacity of the caisson in the laboratory test was less than in the field test by about $30 \%$, and the peak-to-peak stiffness was also less in the laboratory than in the field at large rotations.

Data from the moment-rotation tests, where a packet of 10 cycles was applied to the caissons, are presented in Figs 15(a) and 15(b). The normalised strength and stiffness of the field caisson were significantly lower than those of the laboratory caisson at low to medium rotations, particularly in the positive quadrant. The normalised strength of the field caisson exceeded that of the laboratory caisson only at large displacements. The stiffness of the field caisson in this test was less than in the first test (Fig. 13). This may be due to softening of the Bothkennar silty clay over time, given that the second test was conducted 28 days after the first test, and 44 days after the test pit was excavated. The lower strength and stiffness of the field caisson in the positive quadrant of Fig. 15(b) might also have been caused by an uneven installation. At the end of installation there was a

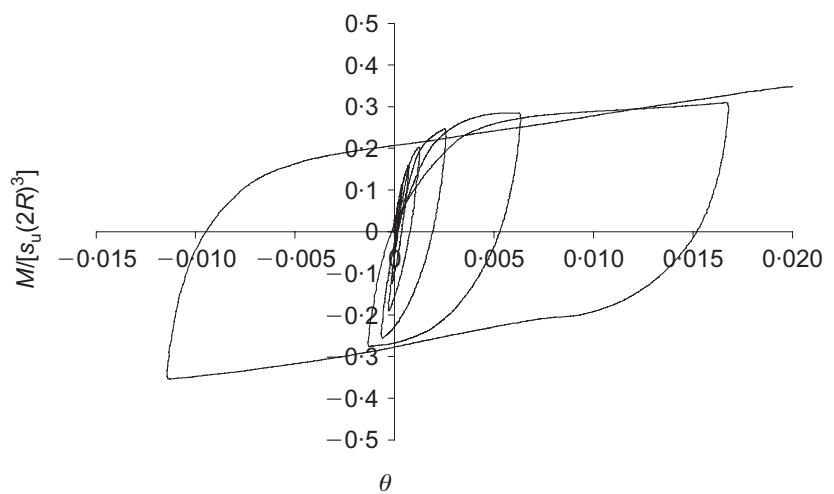

(a)

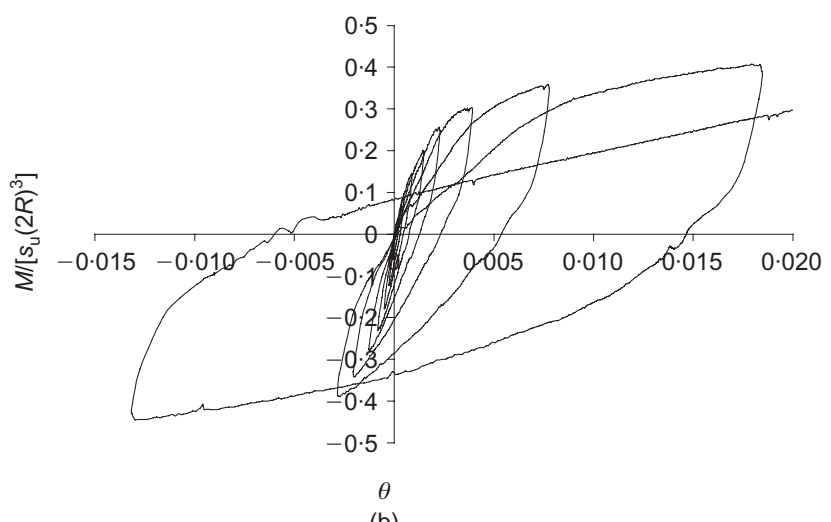

(b)

Fig. 13. Moment loading: (a) laboratory test data in clay, $0 \cdot 2 \mathrm{~m}$ diameter caisson; (b) field test data, $3 \cdot 0 \mathrm{~m}$ diameter caisson

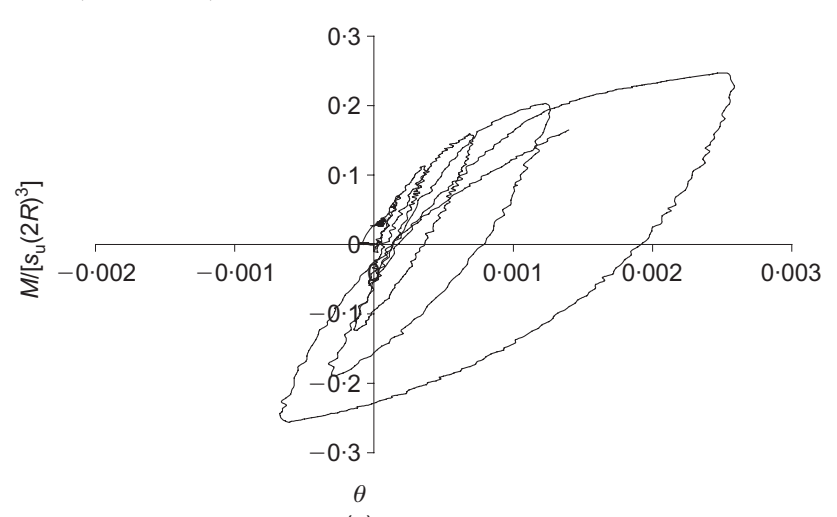

(a)

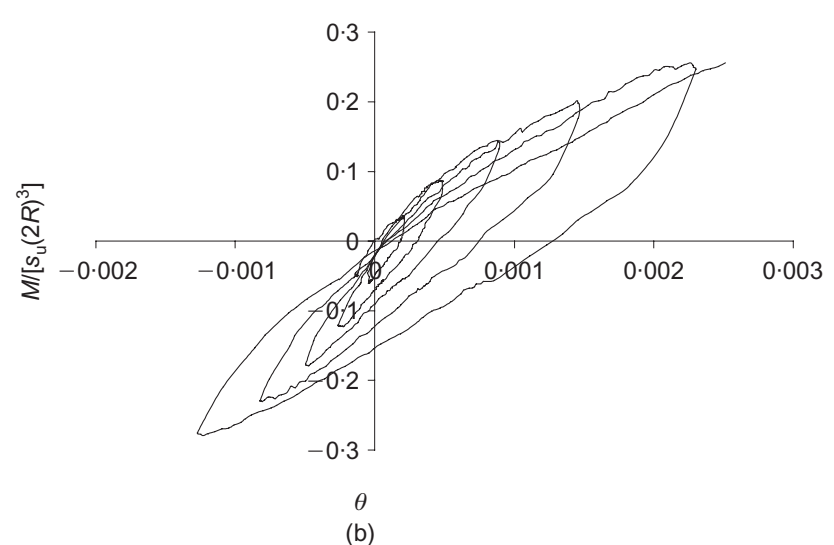

Fig. 14. Small deformation moment loading: (a) laboratory test data in clay; (b) field test data in clay

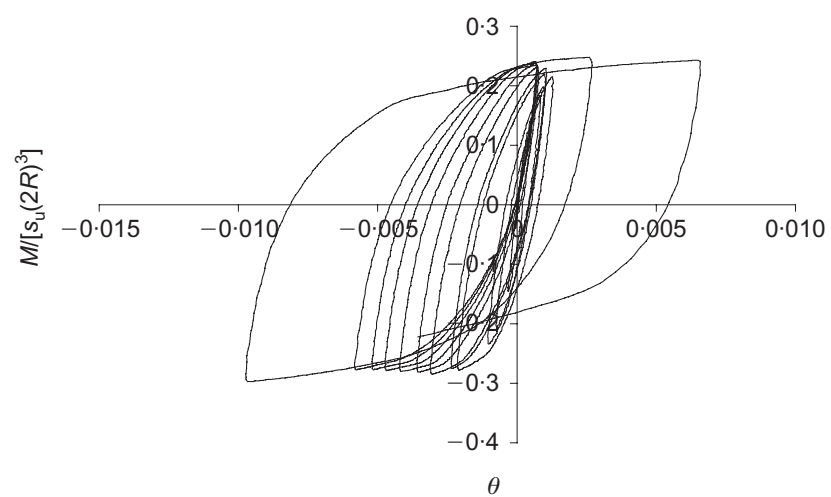

(a)

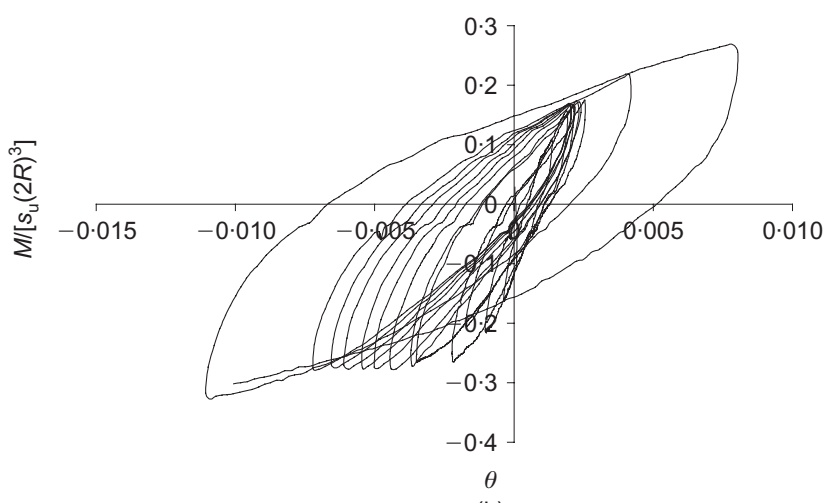

(b)

Fig. 15. Multi-cycle moment loading: (a) laboratory test data, $0.2 \mathrm{~m}$ diameter caisson; (b) field test data, $3.0 \mathrm{~m}$ diameter caisson 
$90 \mathrm{~mm}$ difference of level across the caisson. One side of the caisson might therefore have been in better contact with the clay than the other side.

The normalised unloading stiffness data for the clay tests are shown in Fig. 16. The normalised stiffnesses are very similar, providing a very satisfactory verification of the normalisation procedure involved, bearing in mind that before normalisation the stiffnesses differ by a factor of more than 3900 .

\section{CONCLUDING REMARKS}

Normalisation procedures have been proposed to allow laboratory tests and field trials of foundations in sand and clay to be compared in terms of both stiffness and capacity. These have been applied to a series of laboratory tests specially conducted to mimic a series of field trials. The tests concentrated on cyclic loading conditions relevant to the design of offshore wind turbine foundations.

In sand, the normalisation procedures take account of differing stiffness at different stress levels. Comparisons were made for both cyclic vertical and cyclic moment loading. In both cases the normalisation procedures were found to achieve satisfactory comparison between tests at very different scales. For vertical loading the normalised stiffness within any given cycle was highly repeatable at different scales, but the accumulation of displacement with cycles could not be compared quantitatively. Qualitative comparisons indicated less accumulation of displacement for larger caissons, and (at least at small scale) much more for suction as opposed to pushed installation of caissons. It is speculated that the reasons for both these observations could be related to the size of the zone of soil disturbed by the installation process as a proportion of the caisson size. Moment loading tests in sand indicated an excellent comparison at low rotation amplitudes, with more divergence at higher amplitudes.

Moment loading tests in clay led to similar conclusions as for sand: again the comparison of normalised performance was much closer at small rotation than at large rotation. The former are, however, more relevant to realistic design cases.

It should be borne in mind that the scaling relationships proposed here address stiffness and capacity values that, in absolute terms, differ by several orders of magnitude. In that context, the quality of agreement between laboratory and field results is highly satisfactory, even when some differences, highlighted above, remain. These comparisons lend confidence to the use of such scaling relationships in the design of full-scale structures. Data from loading of such structures, currently not available, would of course be essen-

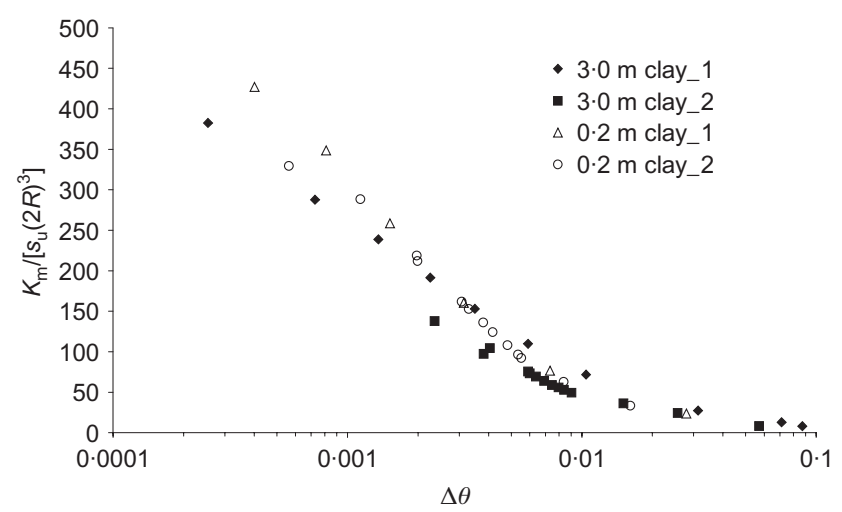

Fig. 16. Summary of normalised unloading stiffness data for moment loading in clay tial for confirmation of the applicability of these procedures across a wider range of scales.

This study demonstrates that laboratory tests, when interpreted carefully in terms of properly chosen dimensionless variables, can be successfully compared with field tests. Used with caution, they therefore offer some predictive capacity. Laboratory testing, centrifuge testing and field testing therefore all have a role in prediction of field performance, and validation of one type of test against another is an important part of this process. We have demonstrated that some aspects of foundation behaviour in laboratory tests (e.g. the stiffness in one cycle) can be more successfully scaled than others (e.g. the accumulation of deformation in many cycles). Laboratory tests offer an advantage of economy that allows more extensive parametric studies than either centrifuge or field testing, and an attractive option is to combine such studies with validation against a smaller number of, inevitably more expensive, centrifuge and field tests.

\section{ACKNOWLEDGEMENTS}

The authors are grateful to the DTI and EPSRC for the funding of this research. The authors would also like to acknowledge the industrial participants in this research project: SLP Engineering Ltd, Fugro Ltd, Garrad Hassan, GE Wind, NEG Micon, Shell Renewables Ltd and HR Wallingford.

\author{
NOTATION \\ $A$, a dimensionless constants \\ $f_{i}$ () dimensionless functions \\ $G$ shear modulus \\ $H$ horizontal load \\ $h$ skirt length \\ $K_{m}$ rotational stiffness \\ $K_{v} \quad$ vertical stiffness \\ $k_{i}$ dimensionless elastic constants \\ $M$ moment \\ $n$ pressure exponent \\ $O C R$ overconsolidation ratio \\ $p_{a}$ atmospheric pressure \\ $R$ radius of foundation \\ $s_{u}$ undrained shear strength \\ $t$ wall thickness \\ $u$ horizontal displacement \\ $V$ vertical load \\ $V_{m}$ mean vertical load \\ $w$ vertical displacement \\ $\gamma^{\prime}$ effective unit weight of soil \\ $\theta$ rotation \\ $\sigma_{v}^{\prime} \quad$ effective stress
}

\section{REFERENCES}

Bang, S., Cho. Y. \& Kim, S. S. (2001). Calibration of suction pile installation design with centrifuge model tests. Proc. 20th Int. Conf. on Offshore Mechanics and Arctic Engineering, Rio de Janeiro, paper OMAE/OSU-5023, pp. 121-125.

Bransby, P. L. (1973). Cambridge contact stress transducers, CUED/C-SOILS/LN2. Cambridge: University of Cambridge.

Butterfield, R. \& Gottardi, G. (1994). A complete three-dimensional failure envelope for shallow footings on sand' Géotechnique 44, No. $1,181-184$.

Byrne, B. W. (2000) Investigations of suction caissons in dense sand. DPhil thesis, University of Oxford.

Byrne, B. W. \& Houlsby, G. T. (2002). Experimental investigations of response of suction caissons to transient vertical loading. Proc. ASCE, J. Geotech. Engng 128, No. 11, 926-939.

Byrne, B. W., Houlsby, G. T., Martin, C. M. \& Fish, P. (2002). 
Suction caisson foundations for offshore wind turbines. Wind Engng 26, No. 3, 145-155.

Byrne, B. W., Villalobos, F., Houlsby, G. T. \& Martin, C. M. (2003). Laboratory testing of shallow skirted foundations in sand. Proc. BGA Int. Conf. on Foundations, Dundee, pp. 161167.

Cho, Y., Lee, T. H., Chung, E. S. \& Bang, S. (2003). Field tests on pullout loading capacity of suction piles in clay. Proc. 22nd Int. Conf. on Offshore Mechanics and Arctic Engineering, Cancun, paper OMAE-2003-37016, pp. 693-699.

Clukey, E. C., Aubeny, C. P. \& Murff, J. D. (2003). Comparison of analytical and centrifuge model tests for suction caissons subjected to combined loads. Proc. 22nd Int. Cont. on Offshore Mechanics and Arctic Engineering, Cancun, paper OMAE2003-37503, pp. 364-397.

Coop, M. R. \& Jovicic, V. (1999). The influence of state on the very small strain stiffness of sands. Proceedings of the conference on pre-failure deformation characteristics of geomaterials, Torino, pp. 175-181.

El-Gharbawy, S. \& Olson, R. (1998). Laboratory modelling of suction caisson foundations. Proc. 10th Int. Conf. on Offshore and Polar Engineering, Montreal, 1, 531-536.

Dyvik, R., Andersen, K. H., Hansen, S. B. \& Christophersen, H. P. (1993). Field tests of anchors in clay. I: Description', Proc. ASCE, J. Geotech. Engng 119, No. 10, 1515-1531.

Hogervorst, J. R. (1980). Field trials with large diameter suction piles. Proc. Offshore Technology Conf., Houston, TX, paper 3817, 217-224.

Houlsby, G. T., Kelly, R. B., Huxtable, J. \& Byrne, B. W. (2005). Field trials of suction caissons in clay for offshore wind turbine foundations. Géotechnique 55, No. 4, 287-296.

Houlsby, G. T., Kelly, R. B., Huxtable, J. \& Byrne, B. W. (2006). Field trials of suction caissons in sand for offshore wind turbine foundations. Géotechnique 56, No. 1, 3-10.

House, A. R. \& Randolph, M. F. (2001). Installation and pull-out capacity of stiffened suction caissons in cohesive sediments. Proc. 11th Int. Conf. on Offshore and Polar Engineering, Stavanger, 2, 574-580.
Kelly, R. B., Byrne, B. W., Houlsby, G. T. \& Martin, C. M. (2003) Pressure chamber testing of model caisson foundations in sand. Proc. BGA Int. Conf. on Foundations, Dundee, 421-432.

Kelly, R. B., Byrne, B. W., Houlsby, G. T. \& Martin, C. M. (2004) Tensile loading of model caisson foundations for structures on sand. Proc. 12th Int. Conf. on Offshore and Polar Engineering, Toulon 2, 638-641.

Larsen, P. (1989). Suction anchors as an anchoring system for floating offshore constructions. Proc. Offshore Technology Conf., Houston, TX, paper 6029, pp. 535-540.

Martin, C. M. (1994). Physical and numerical modelling of spudcan behaviour. DPhil thesis, University of Oxford.

Nash, D. F. T., Powell, J. J. M. \& Lloyd, I. M. (1992). Initial investigations of the soft clay test site at Bothkennar. Géotechnique 42, No. 2, 163-181.

Robinson, P., Wawrzynowicz, A. \& Aldridge, T. (2004). DTI suction caisson project: Cyclic triaxial laboratory testing report: Luce Bay, Report No 443815-1. Fugro Ltd (confidential).

Steensen-Bach, J. O. (1992). Recent model tests with suction piles in clay and sand. Proc. Offshore Technology Conf., Houston, TX, paper 6844 , pp. 323-330.

Tjelta, T. I. (1986). Large-scale penetration test at a deep water site. Proc. Offshore Technology Conference, Houston, TX, paper 5103, pp. 201-212.

Watson, P. G., Randolph, M. F. \& Bransby, M. F. (2000). Combined lateral and vertical loading of caisson foundations. Proc. Offshore Technology Conf., Houston, TX, paper 12195, pp. 797-808.

Whittle, T. (2004). Soils investigation: Static and seismic cone penetration tests at Luce Bay, Scotland, Report No 27517-5. Fugro Ltd (confidential).

Wroth, C. P. \& Houlsby, G. T. (1985). Soil mechanics: property characterisation and analysis procedures. Proc. 11th Int. Conf. Soil Mech. Found. Engng, San Francisco 1, 1-50.

Wroth, C. P., Randolph, M. F., Houlsby, G. T. \& Fahey, M. (1979). A review of the engineering properties of soils with particular reference to the shear modulus, Report CUED/D-SOILS TR75. Cambridge: University of Cambridge. 